\title{
The Activity of Docosahexaenoic Acid (DHA)-rich Phospholipid was different from that of DHA-rich Triacylglycerol in Spontaneously Hypertensive Rats
}

\author{
Yoko IRUKAYAMA-TOMOBE, Mamoru TSUCHIDA, Koji SAKAGUCHI, \\ Hidehiko HIBINO and Yukihisa TANAKA \\ NOF Corporation Tsukuba Research Laboratory \\ (5-10, Tokodai, Tsukuba-shi, Ibaraki 300-2635, JAPAN)
}

Edited by Y. Totani, Seikei Univ., and accepted July 16, 2001 (received for review June 4, 2001)

\begin{abstract}
Spontaneously hypersensitive rats (SHR) were fed test lipid diets for six weeks, which contained 30\%-docosahexaenoic acid (DHA) phospholipid (DHA-PL) extracted from fish roe or 30\%-DHA fish oil (DHA-TG). The control diet contained corn oil in the presence of test lipids.

After feeding, blood pressure in the DHA-TG and DHA-PL diet groups was found significantly lower compared to the control. Serum fatty acid content of dihomo- $\gamma$-linoleic acid (DHLnA) and Arachidonic acid (AA) of the DHA-PL diet group was significantly less than the control or DHA-TG diet group. Serum triacylglycerol, phospholipid and total cholesterol in the DHA-TG and DHA-PL diet groups were significantly less than in the control. Liver total cholesterol in DHA-PL was twice that in the DHA-TG diet group and control. The mechanism for cholesterol removal from blood by DHA-PL would thus appear to differ from that by DHA-TG.

Serum lipid peroxide (LPO) in the DHA-TG and DHA-PL diet groups was essentially the same as in the control.

J. Oleo Sci. 50, 945-950 (2001).

Key words : docosahexaenoic acid, phospholipid, spontaneously hypertensive rat, tail cuff blood pressure
\end{abstract}

\section{1 緒言}

ドコサヘキサエン酸（DHA；22:6 n-3）には脳機能及 び心疾患の予防，抗炎症作用などの機能が報告されてい る。DHA はシクロオキシゲナーゼの基質とはならない (1) が，5あるいは 12-リポキシゲナーゼ（5-LOG，12LOG）の基質となり，DHA の過酸化体がヒドロキシル 体に変換され，血小板凝集能の抑制（2），平滑筋収縮阻 害（3）などを示す。しかしながら，アラキドン酸カス ケードやエイコサノイドへの変換でのみ DHA の効果を 説明する事は難しい。

例えば，細胞膜に取り込まれた DHA がその膜流動性 を高め，外部からの刺激に対する応答に影響を与えてい る事が考元られる。

これまでDHA の生理活性の研究報告では魚油などの トリアシルグリセロール型 DHA (DHA-TG) あるいは 高純度のエチルエステル（DHA-EE）が用いられてき

Corresponding author: Yukihisa TANAKA

E-mail : yukihisa_tanaka@nof.co.jp
た。著者らは生態内ではリン脂質が DHA のリザベィ ヤーとなっている事に注日し，新しいDHA のキャリア としてリン脂質の検討を行った。

リン脂質型の DHA（DHA-PL）を投与して得られる 生理機能についてこれまでにも報告はある。

DHA はリン脂質の sn-2 位に特異的に結合されてい る。その中でも sn-1 位にパルミチン酸あるいはオレイ ン酸が結合したDHA 含有ホスファチジルコリン （DHA-PC）には特に，高い生理活性が報告されている。 Asahi らは奇形腫細胞及び赤芽球性白血病細胞に対する 分化誘導活性を報告している (4)。Hashimoto らは睡眠 時間の増加機能 (5), Izaki らはラットの学習能立進機 能（6）, 記憶維持作用（7）などを報告している。また, 5-LOG の活性阻害から抗炎症作用の可能性（8）が示さ

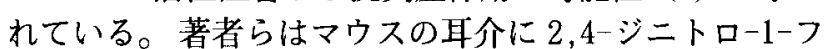
ルオロベンゼン（DNFB）を塗布して作成した耳介浮腫 の抑制によってDHA の抗炎症作用について評価した $(9,10)$ 。DHA を含有するリン脂質を投与したマウスは DHA 含有魚油を投与したマウスより高い抑制効果が䜑 められたことを報告した。井上らはSHR-SPにDHA- 
$\mathrm{PL}$ を投与した結果, 魚油群と比べて脳卒中による死亡 率が低下し，寿命が有意に伸びたことを報告した（11）。 このようにDHAのキャリアの違いによって生理機能に 差が認められる事が示唆された。

さらに, Takama らは四塩化炭素を投与した鶏の肝藏 障害を軽減したことを報告し（12），Hayashi らは慢性 の肝炎患者に対して効果がある事を示唆している（13）。

一方，DHA は酸化を受け易いと考えられている。酸 化を受けやすいことが DHA の医薬品や食品への応用を 難しくしており，さまざまな酸化抑制の検討がされてい る(14)。しかしながら，DHA-PLは DHA-TGあるいは 遊離脂肪酸, DHA-EE に比べて酸化安定性に優れてい る事が報告されている。

Komatsu ら $(15,16)$, 武内ら (17) は DHA-PL を添 加したイワシ油, サケ卵から調製したTGあるいはパー 么油を保存した際に対照群よりも酸素吸収量は少なく, 過酸化物価, カルボニル価の上昇が抑制されることを報 告している。これはリン脂質の含窒素基部分が関与した 抗酸化効果であるとしている。

エイコサペンタエン酸 (C 20:5, EPA) やDHAなどの n-3 系高度不飽和脂肪酸の血清脂質に対する効果として コレステロールや中性脂質の低下, または, 上昇抑制 $(18,19)$ などが報告されている。また，リン脂質それ自 体にむコレステロールの低下作用, LDL の低下作用 (20,21) などが報告されている。しかしながら, 両者の 持つ血清脂質に対する効果は同じであるがその作用機序 が異なる事が予想された。

著者らはこの両者の構造を併せ持つDHA-PL を高血 圧自然発症ラット (Spontaneously Hypertensive Rat: SHR) に投与し，とうもろこし油 (対照群), 及び構成脂 肪酸組成が DHA-PL とほぼ同様である魚油の投与群と 脂質代謝などを比較した。つまり，それぞれ 6 週間投与 の後に血圧の変化及び血清脂質, 血清中の脂質過酸化 物, 臓器の脂質組成などを此較し, 脂質の代謝改善に対 する DHA のキャリアの影響について検討を行った。

\section{2 実験}

\section{$2 \cdot 1$ 飼 料}

$1 \%$ の食塩を含有した低脂肪調整飼料は日本農産工業 (侏)（横浜）より購入した。この飼料の組成を Table 1 に 示した。また，それぞれの飼料は必須脂肪酸の供給のた めに紅花油を $1.2 \mathrm{wt} \%$ 及び試験油脂を $4.8 \mathrm{wt} \%$ 配合し た。対照群は試験油脂の代わりにとうも万こし油を配合 した。試験油脂は DHA-TG と DHA-PL であり, DHATGはカツオより調製した魚油, DHA-PL はイクラを Folch（22）の方法によって抽出して調製した脂質であ る。 DHA-PL の脂質組成は TG, PCとホスファチジル エタノールアミン (PE) の混合物 (1:8:1wt/wt/wt) で ある。全ての油脂には抗酸化剂として $0.2 \mathrm{wt} \%$ の $\alpha$-卜
Table 1 The Composition of the Basal Diet.

\begin{tabular}{lr}
\hline Casein & 20.0 \\
L-Methionine & 0.3 \\
Sucrose & 63.0 \\
Mineral mixture* $^{*}$ & 3.5 \\
Vitamin mixture* & 1.0 \\
Choline bitartrate & 0.2 \\
Cellulose powder & 5.0 \\
Salt & 1.0 \\
Test lipid** & 6.0 \\
\hline & 100.0 \\
* AIN-75 & \\
** Control diet : $4.8 \%$ corn oil $+1.2 \%$ safflower oil & \\
DHA-TG diet : $4.8 \%$ tuna oil $+1.2 \%$ safflower oil & \\
DHA-PL diet : $4.8 \%$ fish roe phospholipid $+1.2 \%$ safflower \\
oil
\end{tabular}

Table 2 The Fatty Acid Composition of Test Diets (GC\%).

\begin{tabular}{lccc}
\hline & Control diet & DHA-TG diet & DHA-PL diet \\
\hline $16: 0$ & 11.2 & 10.6 & 13.1 \\
$16: 1$ & 0.2 & 4.9 & 1.4 \\
$18: 0$ & 2.2 & 2.2 & 8.7 \\
$18: 1$ & 23.9 & 14.5 & 11.9 \\
$18: 2$ & 61.4 & 16.2 & 15.5 \\
$18: 3$ (n-3) & - & 0.6 & 0.2 \\
$20: 4$ (AA) & - & 1.8 & 2.0 \\
$20: 5$ (EPA) & - & 8.9 & 9.0 \\
$22: 6$ (DHA) & - & 21.2 & 25.1 \\
others & 1.1 & 19.1 & 13.1 \\
\hline
\end{tabular}

Control diet : $4.8 \%$ corn oil $+1.2 \%$ safflower oil

DHA-TG diet : $4.8 \%$ tuna oil $+1.2 \%$ safflower oil DHA-PL diet : $4.8 \%$ fish roe phospholipid $+1.2 \%$ safflower oil

コフェノールを添加した。試験油脂を含有した飼料の脂 肪酸組成を Table 2 に示した。

\section{$2 \cdot 2$ SHR の飼育条件}

10 週龄のオス SHR はオリエンタルバイオサービス関 東 (東京) より購入し, 通常食 (日本クレア, 東京: CE2）で 2 週間予備飼育した。血圧と体重を測定し, 各群間 のばらつきが各群で揃うように 1 群を 6 匹とし, 各 1 匹 づつを 1 ケージで 6 週間飼育した。

各飼料は 1 日の必要量をアルミ製の小袋に分包し，袋

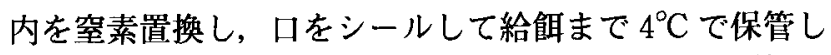
た。毎日新しい飼料を与え，油脂の過酸化少化の影響を 極力避けるようにした。おおむね週に2 回の割合で体重 
測定を行った。

\section{$2 \cdot 3$ 血圧の測定}

各ラットは無麻醉状態で収縮期血圧を尾部脈圧計 (Tail cuff sphygnomanometer MK-1100: 室町機械 (排)，東京）により測定した。測定值はそれぞれ 5 回測定 した平均值で示した。

\section{$2 \cdot 4$ 生化学的試験}

6 週間飼育後, ラットをペントバルビタール $(50 \mathrm{mg} /$ $\mathrm{Kg}$ ）で麻醉下，心臟より採血して屠殺した。血液は氷水 中で約 1 時間静置したのちに $3,500 \mathrm{rpm}, 15$ 分遠心分離 して血清サンプルとした。肝臓，腎臓を摘出し，肝臓は 生理食塩水を門脈から压入して脱血し， $-80^{\circ} \mathrm{C}$ で保管 した。

脂質レベルは血清の脂肪酸組成, 血清 TG, PL, 総コ レステロール (Tcho), 過酸化脂質量 (LPO), さらに肝 機能の指標として GOT，GPT を測定した。なお，一連 の測定はそれぞれ Folch 法に従って, 脂質を抽出し, 測 定キットを用いて測定した。脂質の脂肪酸分析はガスク ロマトグラフィーによって定量分析した。

\section{3 結果と考察}

\section{1 体重の変化}

6 週間の投与期間を通じて体重には有意な差は見られ なかった。すべての個体において毛亚みや䔬の状態など 給餌した飼料による影響は観察されなかった。

\section{$3 \cdot 2$ 血圧の変化}

対照群で 1 匹，DHA-TG 群で 2 匹のラットが測定中 に死亡した。解剖を行っていないので詳細な原因は不明 であるが，測定時のストレスによる脳溢血と思われた。 これらのラットはデータより除外した。6 週間後の血圧 の変化を Table 3 に示した。対照群に比へて DHA-PL 群及び DHA-TG 群では共に有意な低下を示した。個々 のラットの血圧を投与直前と 6 週間後で比較しても対照 群は有意な低下ではなかったが, DHA-PL 群及び DHA-TG 群では有意に低下した。両群の血圧の平均值 も有意に低下した。

\section{$3 \cdot 3$ 血清脂質の脂肪酸組成の変化}

血清脂質の脂肪酸組成は飼料の脂肪酸組成を反映して いた。ジホモガンマリノレン酸 (20:3, n-6;DHLnA), アラキドン酸 (20:4, n-6;AA), EPA, DHA の変化を Table 4 に示した。DHLnA は対照群に比べて DHATG 群は有意な差ではなかったが, DHA-PL 群では有意 な減少があった。DHA-TG 群及び DHA-PL 群いずれ においても投与した飼料の脂肪酸組成を反映し， AA は 対照群に比へて有意に減少し，EPA，DHA は有意に增 加した。また, DHA-PL 群では DHA-TG 群に比べて AA と DHLnA は有意に減少した。EPA及びDHA は 両群間に有意な差は無かった。

ほぼ同様な脂肪酸組成を持っ DHA-TG あるいは DHA-PLの 2 種類の DHA 飼料を投与した結果, その 投与した DHA の脂質クラスが TG と PLであるため, 血清中の AA や DHLnA が $n-3$ 系高度不飽和脂肪酸で ある EPA や DHA に置換される效率 (あるいは速度) が

Table 3 The Effects of Dietary Lipid on Blood Pressure ( $\mathrm{mmHg}$ ).

\begin{tabular}{llll}
\hline & Control diet & DHA-TG diet & DHA-PL diet \\
\hline 0 day & $214.5 \pm 14.7$ & $221.2 \pm 20.4$ & $222.5 \pm 23.1$ \\
42nd day & $220.5 \pm 8.0$ & $191.0 \pm 10.1^{* * *}$ & $202.7 \pm 6.7^{* * *}$ \\
\hline
\end{tabular}

Mean \pm SD

${ }^{*} \mathrm{p}<0.01$ vs control diet, $\quad{ }^{* *} \mathrm{p}<0.01$ vs value of 0 day

Table 4 Effects of Dietary Lipid on Concentration of Serum Fatty Acid ( $\mu \mathrm{M})$.

\begin{tabular}{lccc}
\hline & Control diet & DHA-TG diet & DHA-PL diet \\
\cline { 2 - 4 } DHLnA & $10.0 \pm 1.4$ & $9.5 \pm 1.0$ & $6.9 \pm 0.5^{* *},{ }^{++}$ \\
AA & $607.0 \pm 27.8$ & $224.9 \pm 17.1^{*}$ & $112.4 \pm 4.6^{*},{ }^{+}$ \\
EPA & $1.4 \pm 0.3$ & $92.1 \pm 13.9^{*}$ & $90.4 \pm 5.8^{*}$ \\
DHA & $39.4 \pm 7.1$ & $238.3 \pm 42.5^{*}$ & $275.2 \pm 24.1^{*}$ \\
\hline
\end{tabular}

\footnotetext{
Mean \pm SEM

${ }^{*} \mathrm{p}<0.01$ vs control diet, ${ }^{* *} \mathrm{p}<0.05$ vs control diet

$+\mathrm{p}<0.01$ vs DHA-TG diet, $\quad++\mathrm{p}<0.05$ vs DHA-TG diet
} 
影響を受けることが示唆された。DHA-PL群の方が DHA-TG 群に比べて AA， DHLnA 濃度が有意に低下 したことから DHA が結合する脂質クラスが n-6 系高度 飽和脂肪酸の置換の効率（速度）に影響を及ぼしたこと が示された。この結果，投与した脂質の脂質クラスは, $\mathrm{n}-6$ 系あるいは $\mathrm{n}-3$ 系高度不飽和脂肪酸から由来して産 生されるサイトカインの産生比率にも影響を与える可能 性が考えられ，そのサイトカインによって誘導される現 象（症状）が影響を受けることが示唆された。

\section{4 血清, 臓器脂質の変化}

血清 TG 濃度は対照群に比へ DHA-PL 群及び DHATG群いずれむ有意に減少した。DHA-TG群では DHA-PL 群より減少の傾向があった（Table 5)。血清 PL 濃度は対照群に比へ DHA-PL 群及び DHA-TG 群 いずれも有意に減少した。血清 Tcho 濃度は対照群と比 べて DHA-TG 群及び DHA-PL 群で有意に減少した。 DHA-PL 群では DHA-TG 群より減少の傾向があった (Table 5)。肝臓 TG 濃度は対照群と DHA-PL 群では有 意な差はなかったが，DHA-TG群では対照群及び DHA-PL 群と比較して有意に減少した。肝淢 PL 濃度 は DHA-TG 群及び DHA-PL 群で低下の傾向が見られ たが有意な低下ではなかった。肝胹 Tcho 濃度は対照群 と比べて DHA-TG 群では有意な差は無かったが, DHA-PL 群では約 2 倍に増加し (Table 5), 対照群及び DHA-TG 群に比べ有意に高かった。

腎臟の脂質組成では TG 濃度, PL 濃度, Tcho 濃度の いずれも3 群間に有意な差は認められなかった（Table 5)。

血清の LPOは 3 群間で有意差は見られなかった (Table 6)。つまり, 本実験で示したように約 6 週間の DHA 投与では SHR の場合, 生体内の抗酸化機能は有
効に作用し，生体内中での DHA の過酸化は十分に抑制 されたものと考えられた。つまり DHA の過酸化物によ る組織への障害はほとんどないことが示唆された。

GOT, GPT は 3 群間で有意な差は認められなかった (Table 7)。

多くの研究によりヒトの血清中の脂質組成, 特に, コ レステロール濃度が上昇し，動脈で過酸化反応や炎应反 応が併発して病変が発症することによって動脈硬化症が 若起されることが明らかとなっている（23）。高度不飽和 脂肪酸にはコレステロール低下作用が報告されている。 その作用機序は明確になっていないが, 高度不飽和脂肪 酸のコレステロールエステルが肝臓や組織によって急速 に代謝され，その結果，コレステロールの代謝回転や排 出を促進する可能性が報告されている $(24,25)$ 。本研究 では DHA-PL 群では血清中の Tcho が対照群や DHATG 群より減少し, 逆に肝臓中では Tchoは有意に高 まった。この結果から血清中のコレステロールの回収は TGよりPLの方が優位であることが推測された。つま り, DHA-TG 群と DHA-PL 群とではコレステロール 代謝の作用機序に差異があることが示唆された。黒田ら は SD 系ラットにオキアミから調製した DHA-PLを 2 週間投与している $(26,27)$ 。血清 Tcho は魚油群及び魚 油と卵黄リン脂質を併せて投与した群, DHA-PL 群で 減少しており，本報告の結果と一致している。

以上のことから DHA-TG, DHA-PL 群では血圧は対 照群に比べ，いずれも同様に降下したが，その現象は同 じでむその作用機序は異なることが推定された。

魚油に含まれるEPAの高血圧に対する治療効果は良 く知られているが，これは強い血管弛縟作用を持つプロ スタサイクリン (PG) $\mathrm{I}_{2}$ の産生が増強され, 血管収縮作 用を持つトロンボキサン (TX) $A_{2}$ の産生が減少するこ

Table 5 Effects of Dietary Lipid on Concentration of Serum, Liver and Kidney Lipids.

\begin{tabular}{|c|c|c|c|}
\hline & Control diet & DHA-TG diet & DHA-PL diet \\
\hline \multicolumn{4}{|l|}{ Serum } \\
\hline triacylglyceride $(\mathrm{mg} / \mathrm{dl})$ & $221.0 \pm 45.7$ & $83.3 \pm 17.2^{*}$ & $135.5 \pm 14.2^{*}$ \\
\hline phospholipid $(\mathrm{mg} / \mathrm{dl})$ & $214.0 \pm 11.1$ & $149.8 \pm 9.6^{*}$ & $141.7 \pm 4.9^{*}$ \\
\hline total cholesterol $(\mathrm{mg} / \mathrm{dl})$ & $100.0 \pm 4.0$ & $74.0 \pm 4.8^{*}$ & $61.3 \pm 2.8^{*}$ \\
\hline \multicolumn{4}{|l|}{ Liver } \\
\hline triacylglyceride $(\mathrm{mg} / \mathrm{dl})$ & $50.5 \pm 10.5$ & $29.7 \pm 4.3^{*}$ & $62.6 \pm 6.1$ \\
\hline phospholipid (mg/dl) & $75.2 \pm 8.3$ & $65.6 \pm 6.9$ & $66.2 \pm 2.8$ \\
\hline total cholesterol $(\mathrm{mg} / \mathrm{dl})$ & $9.3 \pm 0.8$ & $8.7 \pm 0.8$ & $18.4 \pm 1.5^{*}$ \\
\hline \multicolumn{4}{|l|}{ Kidney } \\
\hline triacylglyceride $(\mathrm{mg} / \mathrm{dl})$ & $12.9 \pm 0.4$ & $9.8 \pm 1.2$ & $10.1 \pm 1.7$ \\
\hline phospholipid (mg/dl) & $48.8 \pm 2.7$ & $50.5 \pm 1.3$ & $51.4 \pm 1.7$ \\
\hline total cholesterol $(\mathrm{mg} / \mathrm{dl})$ & $14.2 \pm 0.7$ & $15.1 \pm 0.3$ & $16.1 \pm 0.6$ \\
\hline
\end{tabular}

Mean \pm SEM

${ }^{*} \mathrm{p}<0.01$ vs control diet 
Table 6 Effects of Dietary Lipid on Concentration of Serum Peroxidized Lipid.

\begin{tabular}{lccc}
\hline & Control diet & DHA-TG diet & DHA-PL diet \\
\cline { 2 - 3 } & $4.3 \pm 0.2$ & $4.8 \pm 0.2$ & $5.0 \pm 0.2$ \\
\hline Mean \pm SEM & & &
\end{tabular}

Table 7 Effects of Dietary Lipid on Concentration of GOT and GPT.

\begin{tabular}{lccc}
\hline & Control diet & DHA-TG diet & DHA-PL diet \\
\hline GOT (IU/L) & $298.8 \pm 39.4$ & $340.5 \pm 42.6$ & $310.7 \pm 36.3$ \\
GPT $($ IU $/$ L $)$ & $73.2 \pm 5.5$ & $74.8 \pm 2.0$ & $81.5 \pm 5.7$ \\
\hline
\end{tabular}

Mean \pm SEM

とによって起こるとされている。血管弛緩作用を持つ因 子として一酸化窒素 $(\mathrm{NO})$ などがあるが，魚油は内皮依 存性の血管他緩反応を増強するという報告 (28) がある。 また，SHRにスーパーオキシドジスムターゼ（SOD）を 投与すると血圧は降下する（29）。これはNO をトラッ プする $\mathrm{O}_{2}$ ラジカルが SOD投与により代謝されること によると考えられている。

血圧を決定する最も重要な要素は心拍出量と末梢血管 抵抗である。この両者は交感神経, 体液量, 踈機能, 木 ルモンなどにより調節され，高血圧はこれらのバランス 異常によって発生する。腸間膜動脈血管床は最も血压に 影響を与える末梢抵抗血管であるが，魚油はSHR から 単離した晹間膜動脈血管床の収縮反応を減少するという 報告がある(30)。

魚油をはじめとした研究で, 高血圧に対する作用機序 は解明が進んでいる。これまでは DHA の供給の形態と してのリン脂質については検討されていない。本報告で は投与形態の違いによる作用の差異を示し，作用機序の 違いの一部を考察した。

しかしながら，大豆油と大豆りン脂質ではその生理機 能に違いがあることと同様，DHA の場合も同じ脂肪酸 組成でも投与される脂質クラスによって作用機序が異な ることが示唆された。

\section{4 総 括}

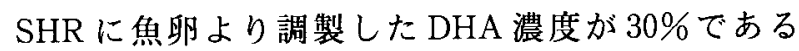
DHA-PL と $30 \%$ DHA を含むDHA-TG を投与した。 DHA-TG 投与群と DHA-PL 投与群では対照群に比へ 血圧は有意に降下し，血清の DHLnA 及び AA 濃度は DHA-PL 投与群では DHA-TG 投与群及び対照群より 有意に低下した。血清の TG, PL, Tcho 濃度は DHATG 及び DHA-PL 投与群では対照群に比べ有意に低下 した。DHA-PL 投与群の肝臓の Tcho 濃度は DHA-TG 投与群及び対照群に比べ 2 倍高くなった。これらより, 血清からのコレステロール除去の作用機序が DHA-PL
投与群と DHA-TG 投与群では異なることが予測され た。血中の LPOは 3 群間で有意な差はなく，摂食した DHA や EPA な゙の高度不飽和脂肪酸は SHR の生体内 の抗酸化機構によっての過酸化は抑制された。

本報告では明確な DHA-PLによる血圧降下作用の機 序は結論付けられなかった。しかしながら， DHA-TG のそれとは差があることが示唆された。

\section{References}

1. Fisher, S., von Schacky, C., Siess, W., Strasser, T. \& Weber, P. C. (1984) Biochem. Biophys. Res. Commun., 120, 907-918.

2. Croset, M., Sala, A., Folco, G. \& Lagarde, M. (1988) Biochem. Pharmacol., 37, 1275-1280.

3. Karanian, J.W., Kim, H.Y., Shingu, T., Yergey, J.A., Yoffe, A. \& Salem, N. Jr. (1989) Biomed. Biochim. Acta, 47, S79-S82.

4. Suzuki, M., Asahi, K., Isono, K., Sakurai, A. \& Takahashi, N. (1992) Develop Grouth \& Differ, 34, 301-304.

5. Hashimoto, M., Gong, X., Izaki, Y., Iriki, M. \& Hibino, H. (1993) Neuroscience Letter, 158, 29-32.

6. Izaki, Y., Hashimoto, H., Arita, J., Iriki, M. \& Hibino, H. (1994) Neuroscience Letter, 167, 171-174.

7. Izaki, Y., Hashimoto, M. \& Arita, J. (1999) Neuroscience Letter, 260, 146-148.

8. Corney, E.J., Shih, C. \& Cashman, J.R. (1985) Proc. Natl. Acad. Sci. USA, 80, 3582-3584.

9. Morizawa, K., Tomobe, Y.I., Tsuchida, M., Nakano, Y., Hibino, H. \& Tanaka, Y. (2000) J. Jpn Oil Chem. Soc. (J. Oleo Sci. ), 49, 59-65.

10. Tanaka, Y., Tomobe, Y.I., Morizawa, K., Tsuchida, M., Nakano, N. \& Hibino, H. (2000) J. Jpn Oil Chem. Soc. (J. Oleo Sci.), 49, 75-79.

11. Inoue, Y., Kanada, T., Kayama, M., Morizaki, M. \& Saito, Y. (1999) J. Lipid Nut., 8, 120.

12. Takama, K., Suzaki, T., Fukunaga, K. \& Suzuki, S., Seafood Science and Technology, Bigh E.G., Edior, 1992 
Fishing News Books Oxford London 210.

13. Hayashi, H., Tanaka, Y., Hibino, H., Umeda, Y., Kawamitsu, H., Fujimoto, H. \& Amakawa, T. (1999) Current Medical Research and Opinion, 15, 177-184.

14. Inoue, Y., Misawa, Y. \& Kondo, H. (1992) New Food Industry, 34, No.10, 43-48.

15. Komatsu, I., Yasuda, T., Suzuki, T., Fukunaga, K., Suzuki, S. \& Takama, K. (1990) Bull. Fac. Hokkaido. Univ., 41, 232-239.

16. Komatsu, I., Yasuda, T., Fukunaga, K., Suzuki, T., Suzuki, S. \& Takama, K. (1991) Nippon Shokuhin Kogyo Gakkaishi 38, 633-639.

17. Takeuchi, M., Hara, S., Hibino, H., Tanaka, Y. \& Totani, Y. (1997) J. Jpn Oil Chem. Soc. (J. Oleo Sci.), 46, 14891494.

18. Nakajima, S., Suetsuna, K. \& Tsuchiya, T. (1994) Nippon Suisangakkaishi, 60, 635-639.

19. Ikeda, I., Wakamatsu, K., Inayoshi, A., Imaizumi, K., Sugano, M. \& Yazawa, K. (1994) J. Nutr., 124, 18981906.

20. Kimura, T. \& Kudo, H. (1968) Naika, 21, 535-543.
21. Rampone, A.J. \& Machida, C.M. (1981) J. Lipids Res., 22, 744-752.

22. Folch, J., Lee, M. \& Sloane, Stanley, G.H. (1957) J. Biol. Chem., 226, 497-509.

23. Ross, R. (1990) Nature, 362, 801-809.

24. Paul, R., Ramesha, C.S. \& Ganguly, J. (1980) Adv. Lipid Res., 17, 155-171.

25. Herold, P.M. \& Kinsella, J.E. (1986) Am. J. Clin. Nutr., 43, 566-598.

26. Kuroda, K., Kobatake, Y., Nishide, E. \& Yamaguchi, M. (1987) Eiyogakuzasshi, 45, 263-274.

27. Kuroda, K., Hosoyamada, Y. \& Kobatake, Y. (1997) J. Jap. Soc. Nutr. Food Sci., 50, 25-30.

28. Shimokawa, H., Lam, J.Y., Chesebro, J.H., Bowie, E.J. \& Vanhoutte, P.M. (1987) Circulation, 76, 898-905.

29. Nakazono, K., Watanabe, N., Matsuno, K., Sasaki, J., Sato, T. \& Inoue, M. (1991) Proc. Natl. Acad. Sci. USA, 88, 10045-10048.

30. Chu, Z.M., Yin, K. \& Beilin, L.J. (1992) Clin. Exp. Pharm. Physiol., 19, 177-181. 